\section{New ports of the New World: Angra, Funchal, Port Royal and Bridgetown}

The International Journal of Maritime History 2017, Vol. 29(I) 155-174

(C) The Author(s) 2017

Reprints and permissions: sagepub.co.uk/journalsPermissions.nav DOI: I0.II77/084387|4|6677952 journals.sagepub.com/home/ijh

@SAGE

\author{
Ana Catarina Abrantes Garcia \\ CHAM - New University of Lisbon, Portugal
}

\begin{abstract}
This article presents a comparative analysis of the port systems of the Portuguese and British Empires in the Atlantic during the seventeenth and eighteenth centuries. It is based on the study of four insular ports under the sovereignty of these two imperial polities: Angra in the Azores, Funchal in Madeira, Bridgetown in Barbados, and Port Royal in Jamaica. The aim of the analysis is to compare the main factors that led to the choice of these sites as key places in the structure of the respective Portuguese and British imperial models, how they developed to satisfy trade needs and their most significant problems, as well as the extent to which the development of these colonies conformed to what was 'expected' of each imperial project, taking into account the geographical, economic and social factors of the respective port cities. The methodological approach to the study of these Atlantic insular ports brings together data from landscape archaeology, nautical and underwater archaeology, together with historical documentation and cartography.
\end{abstract}

\title{
Keywords
}

Atlantic, England, maritime empires, ports, Portugal

The opening of new sea routes in the Atlantic Ocean from the fifteenth century onwards witnessed the development of trading exchanges in waters never before navigated by European polities. Columbus' first voyage in 1492 signalled the beginning of navigation to Central America, while the discovery of Brazil in April 1500 by Pedro Álvarez Cabral paved the way for trans-oceanic links with South America. For the first time, the two sides of the Atlantic were connected - Europe with Africa, and both with America - on a

\section{Corresponding author:}

Ana Catarina Abrantes Garcia, Portuguese Centre for Global History (CHAM), UID/HIS/04666/20I3,

Faculdade de Ciências Sociais e Humanas, Universidade Nova de Lisboa, Avenida de Berna, 26-C, 1069-06I, Lisboa, Portugal.

Email: catarinagarcia@fcsh.unl.pt 
scale that intensified as the early modern era progressed. Regular contact and interaction between people, cultures and commodities created an 'Atlantic world as a unit'.1

The Portuguese and Spanish started their overseas expansion over a century before northern European nations, with the English not colonizing Jamestown until 1607, and Barbados until 1627..$^{2}$ In this context, islands and Atlantic archipelagos played a very important role, in some cases becoming essential strategic points in Europe's overseas connections. The Azores, Madeira, the Canary Islands, Cape Verde Islands and other islands in the Atlantic, South Atlantic and Caribbean, provided 'port of call' facilities for ships - that is, watering, shelter or repairs, providing assistance and protection on long trips.

The Atlantic islands thus became essential to navigation, due to the natural weakness and low speeds of sailing ships. For the Portuguese Empire, they were first seen as ports of call for the replenishment of shipping, and they soon began to serve as strongholds beyond the Portuguese mainland, which the crown thought it essential to settle in order to ensure it controlled these islands. In the English case, the start of Atlantic expansion in the late sixteenth and early seventeenth centuries had a political, economic and social dynamic that was quite different from those of southern Europe, with less experience of overseas expansion, but a long tradition of competition between ports to acquire trading advantages on northern European routes and in the ports fringing the North Sea and the Baltic. ${ }^{3}$

During the 'age of discovery', the central powers in Lisbon and London recognized that the insular territories were not only essential as ports of call, but also as new territories, which entailed expansion into the mainland. In this context, new ports were founded on sites without previous human occupation to guide them or, in cases where indigenous settlements existed, without existing port structures to indicate the best location.

\section{Geography and geomorphology}

\section{Macaronesia and Caribbean Islands}

Although all positioned in Atlantic space, the islands of Terceira, Madeira, Barbados and Jamaica have different geographical locations and geological characteristics. Terceira and Madeira are located in Macaronesia as we can see in Figure 1, showing all the archipelagos of Madeira, the Azores, the Canary Islands and Cape Verde, whereas Jamaica and Barbados are located in the Caribbean Sea, shown in Figure 2. In this map it's possible to localize all the islands and see in detail the position of Barbados outside of the lesser Antilles alignment, in the Barbados Ridge. However, despite the similarity of both insular groups, each island has different geomorphologies, topographies, soil types,

1. Alan L. Karras and John Robert McNeill, Atlantic American Societies from Columbus through Abolition, 1492-1888 (London, 1992), 1-12.

2. Abigail L. Swingen, Competing Visions of Empire: Labor, Slavery, and the Origins of the British Atlantic Empire (London, 2015), 16-17.

3. While for the Portuguese, led by the crown, the idea of crusade and expanding new trading routes was one of the major reasons for the first voyages on the open Atlantic sea, to the English in the seventeenth century, expansion to the Caribbean islands was a venture financed by private trading companies with the goal of cultivating land as an alternative labour system to an over-populated country: England. Swingen, Competing Visions, 11-17. 


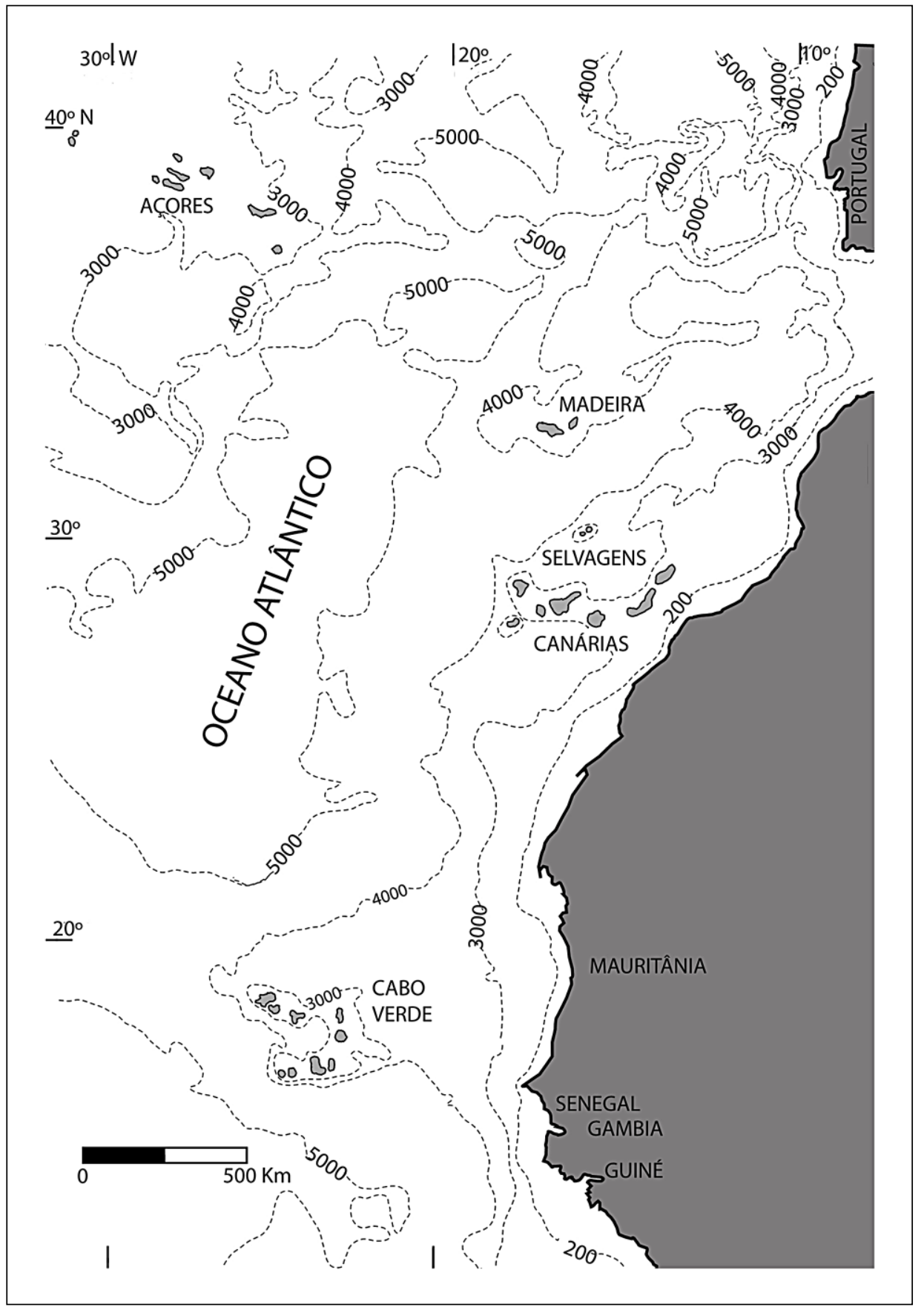

Figure I. Macaronesia archipelagos.

Source: Based on Raoul C. Mitchell-Thomé, Geology of the Middle Atlantic Islands (Berlin, 1976), 6. 


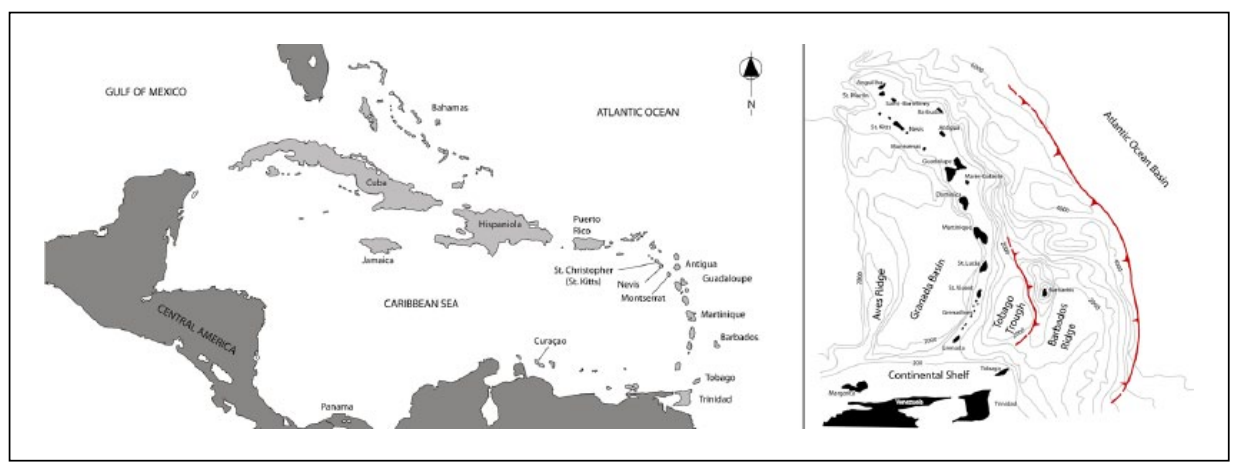

Figure 2. Caribbean Islands and geological position of the Lesser Antilles.

Source: Based on Abigail L. Swingen, Competing Visions of Empire: Labor, Slavery, and the Origins of the British Atlantic Empire (London, 2015) and Robert C. Speed, 'Geology and Geomorphology of Barbados: A Companion Text to Maps with Accompanying Cross Sections, Scale I:10,000', in Christine Speed and Richard Sedlock, eds., The Geological Society of America (Boulder, CO, 2012).

water supplies and shorelines. This difference is important for the understanding of the settlement process and of location choices.

\section{Angra, Terceira}

The island of Terceira, in the Azores, is part of the central group of this nine-island archipelago. Angra do Heroísmo, where the main port was located, is geologically positioned on the southern border of Moirão Mountain. The port city extended along a south-north orientation over an irregular topography, and had a protected bay with only a few access points to the sea in the form of small coves located between the cliffs of Porto Pipas to Canta Galo, and Praínha to Porto Novo. ${ }^{4}$ This geomorphology, although seemingly harmful, was advantageous to the defence and protection of the city itself, with cliffs working as natural walls, eliminating the need for the construction of defensive structures.

Constructing port facilities along Angra's coastline or in the bay's aquatic space, such as piers or mooring points, was problematic because of its geomorphological features and because of its vulnerability to storms or bad weather from the south. In Angra's case, the improvement of port facilities was very difficult, due to the absence of geological points on which a breakwater or other large protection infrastructures could be built, while limited financial resources, ${ }^{5}$ knowledge and technical limitations of the time hindered the transformation of the port. ${ }^{6}$

4. Before the Corte Real road was built in the nineteenth century, these cliffs on the coastline were insurmountable barriers.

5. It was common for the city's Senate to announce a lack of liquidity when faced with payments for port structures, like the principal quay of the port. Ana Catarina Garcia, 'O Porto de Angra no Século XVII e o Sistema Portuário do Atlântico’ (Unpublished MA thesis, Azores University, 2008), 77 and 110.

6. Around the bay, depths could descend directly to 40 metres close to Monte Brazil's cliffs. Inside the bay, the sandy bottoms are around 30 metres deep mixed with rocky areas close to 


\section{Funchal, Madeira}

Funchal is located on the biggest island of the Madeira archipelago, emerging from a submarine plateau located at a depth of about 5000 metres. Around 80 per cent of the island's coastline surface is composed of steep slopes and ravines with relatively high altitudes, some of them over 1000 metres above sea level. The coastline offers only a few small coves, with no sandy beaches, only rolled coves of gravel and stone, ${ }^{7}$ lacking elements such as islets or crags that could have worked as barriers and natural protective elements for a port. Even so, there are some bays, such as Lido, Funchal and Machico, where geographical features allowed some protected areas and where, as a logical consequence, the principal ports of the island emerged.

The area of Funchal belongs geologically to the 'Funchal unit' ${ }^{8}$ It is characterized by flows that originated as water courses. We can today identify brooks that crossed the city, coming from the highest points of the hills. Water courses throughout the beaches on the coast rolled out various deposits of grain-sized gravel. Funchal's lower part, the 'central beach', is characterized by that gravel, where most of the beaching manoeuvres took place for loading and unloading goods. This was the best location for landward connections in Funchal and, until the nineteenth century, there was no better option.

Undersea eruptions caused islets on the western part of the bay, in particular that of Pontinha. It was here that two of Funchal's defensive structures were built, ${ }^{9}$ and that ships might berth as an alternative to 'central beach'. ${ }^{10}$

\section{Bridgetown, Barbados}

The island of Barbados is positioned $145 \mathrm{~km}$ east of the Lesser Antilles arc of islands in the Caribbean Sea, located on the Barbados Ridge, basically of sedimentary formation, mainly coral reefs. ${ }^{11}$ One important characteristic of the geology of Barbados, relevant to the understanding of the British settlement, is the lack of fresh water and the absence of permanent rivers or streams, except in the Scotland district. ${ }^{12}$ This difficulty of finding water in the island is mentioned as early as 1678 in Richard Blome's description: 'This isle is not over-plentifully watered with rivers, or fresh springs ... and for the most part

the eastern part of Monte Brazil. Depths of around 20-25 metres were ideal for shipping and anchorage.

7. Raoul C. Mitchell-Thomé, Geology of the Middle Atlantic Islands (Berlin, 1976), 18-22.

8. António Brum da Silveira et al., Notícia Explicativa da Carta Geológica da Ilha da Madeira na escala 1: 50.000, Folhas A e B (1st edition, Funchal, 2010).

9. The two forts were named, Forte da Pontinha and S. José Fort. In the latter it is still possible to identify a staircase carved into the rock, used as a primitive quay.

10. Brian Philip, Élvio Sousa and Rafael Nunes, Escavações Arqueológicas no Forte de São José, Funchal: Três séculos de Humanização de um Rochedo à beira Mar (Funchal, 2013).

11. Robert C. Speed, 'Geology and Geomorphology of Barbados: A Companion Text to Maps with Accompanying Cross Sections, Scale 1:10,000', in Christine Speed and Richard Sedlock, eds., The Geological Society of America (Boulder, CO, 2012).

12. Hilary McD Beckles, A History of Barbados: From Amerindian Settlement to Caribbean Single Market (Cambridge, 2006), 8. 
even, there are several Pools or Ponds; besides, most Houses have Wells or Cisterns which are always supplied with Rain -Water'. ${ }^{13}$

Bridgetown, the most important port-city of Barbados, lies on the south-western coast of the island, covering an area of about $39 \mathrm{~km}^{2}$. The town's location was originally a swamp, which was quickly drained and filled in to make way for the city's early development. The Careenage and Constitution rivers run across the city. These two watercourses provide direct access to the city for medium-sized ships. Although moderately shallow, the Careenage divides Bridgetown into two parts. Carlisle Bay provides a large space for shipping, protected from north-east winds, with deep waters and good coral-limestone for anchorage, where about 200 ships could lay at anchor, according to Blome's descriptions. ${ }^{14}$

\section{Port Royal, Jamaica}

Jamaica is located in the Greater Antilles archipelago, in the north-western section of the Caribbean Sea. The coastal plains of Jamaica were, and still are, progressively raised by alluvial deposition. Along the submerged coastlands, an underwater shelf stretches for several miles along the south coast, between the Palisadoes and the mouth of the Black River. This submarine platform is covered mostly by scattered reefs giving rise to a number of cays, of which the most important are Port Royal, Morant Point and Portland Bight. ${ }^{15}$

In this context, Port Royal, located on Jamaica's south coast, was grounded on a Palisadoes spit originated by torrential rivers coming down from the Kingston Mountains, north of Port Royal. ${ }^{16}$ Those torrents spilled out gravel-laden sediments into the Caribbean which were pushed by prevailing south-easterly winds and westerly currents to produce an extensive shelf. The Palisadoes spit has formed a more or less continuous line, at least during the past 400 years, a recent phenomenon caused by the unconsolidated ground-level materials composed essentially of sand, gravels and silts. Close to Port Royal, sea bottoms are very deep as in the Yallahs Basin, a submarine canyon that fans and runs close to the eastern margin at an average depth of 1350 metres, influencing currents and navigation in the entrance to Kingston bay.

\section{First perceptions of landscape and ports location: Successes and failures}

The brief geological and geographical descriptions of each case study - Angra, Funchal, Port Royal and Bridgetown - are important to understand the natural geomorphologies

13. Richard Blome, A Description of the Island of Jamaica with the Other Isles and Territories in America to Which the English Are Related, Viz. Barbadoes, St. Christophers, Nievis or Mevis, Antego, St. Vincent, Dominica, Montserrat, Anguilla, Barbada, Bermudes, Carolina, Virginia, Maryland, New-York, New-England, New-Found-Land: Together with the Present State of Algiers (London, 1678), 29.

14. Blome, A Description, 30.

15. James L. Pindell and Stephen F. Barrett, 'Geological Evolution of the Caribbean Region: A PlateTectonic Perspective', in G. Dengo and J. E. Case, eds., The Caribbean Region: Geological Society of America, The Geology of North America (Boulder, CO, 1990), H, 405-32.

16. R. M. Bent and E. L. Bent-Golding, A Complete Geography of Jamaica (London and Glasgow, 1966), 17. 


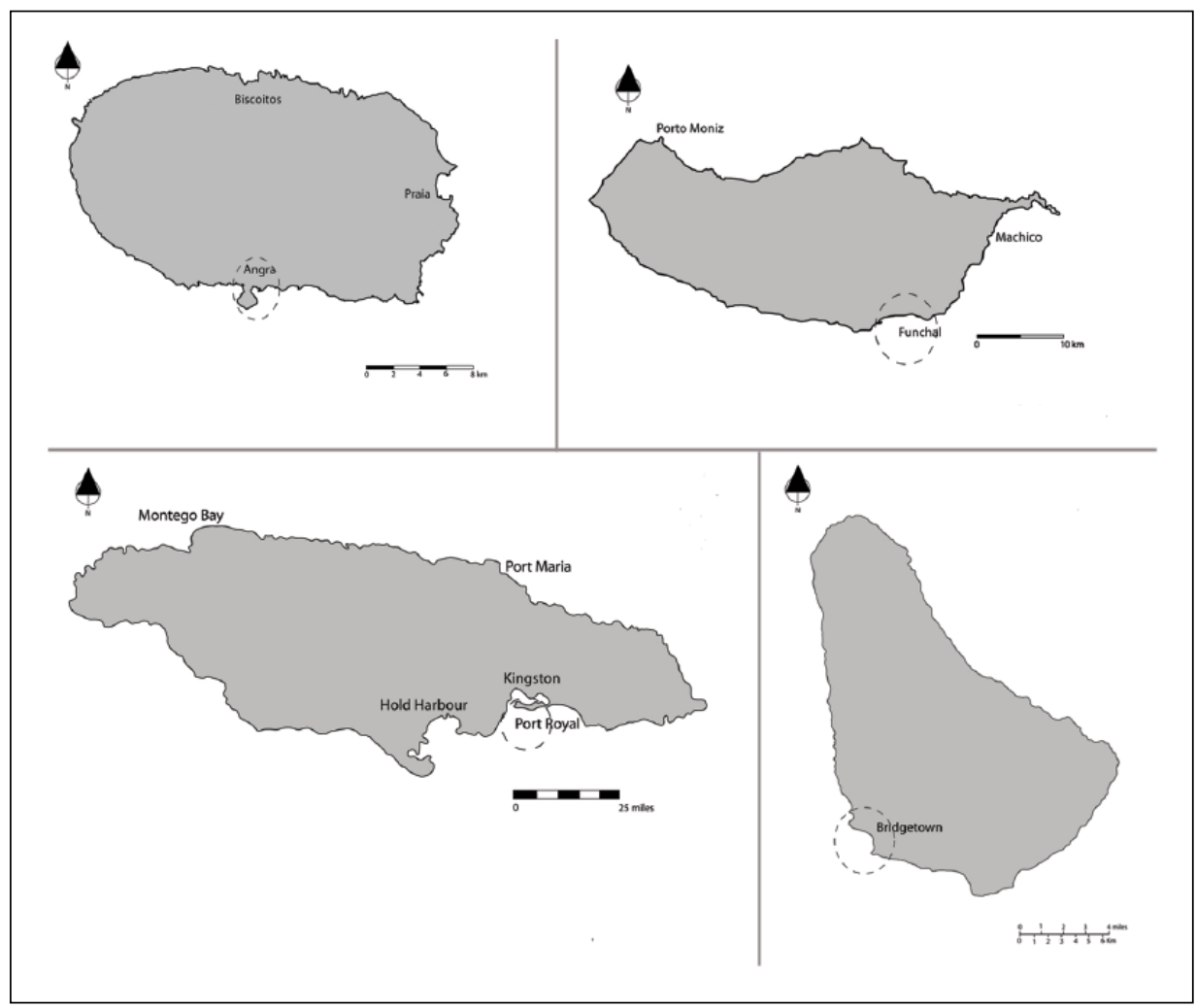

Figure 3. The southerly positioning of Angra, Funchal, Port Royal and Bridgetown.

of each harbour's location. As we shall see, each location was chosen for different geographic, economic, strategic and defensive reasons.

A first observation reveals that all four ports are positioned on the south or south-west coasts of their respective islands, as Figure 3 indicates. This common positioning is not a coincidence, but a pattern that can be observed in most early modern insular Atlantic ports. Natural limitations for building major protective infrastructures, and the absence of protected estuaries, as they existed in continental Europe, made the islands far more vulnerable to bad weather than continental ports. Since the prevailing winds in the North Atlantic come from the north and west, the southerly positioning of ports is an obvious consequence. Although marine erosion is more severe on north-facing shores, the places with older erosion or geological phenomena that formed protected bays mostly face south.

Matching these data with the islands' first historical descriptions by explorers explains why some bays were selected as the best locations for future ports. This first evaluation was made by an empirical perception of the potentialities of these sites such as: good anchorage places, ships' safety, depth and bottom typology, ease of land access. In the narratives of Gaspar Frutuoso, a late-sixteenth-century Portuguese chronicler, the exploration of Madeira by Captain João Gonçalves Zarco in 1419 progressed from Machico to 


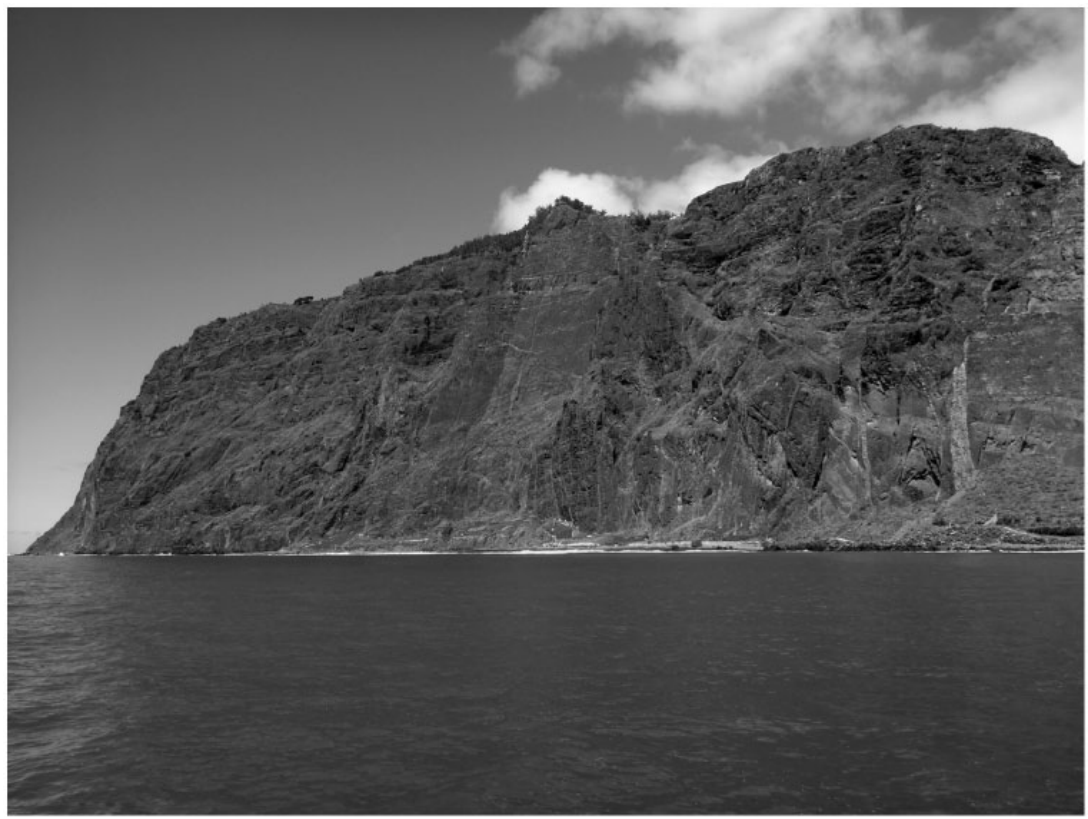

Figure 4. High cliffs of Cabo Girão.

(Photo: Ana Catarina Abrantes Garcia).

Cabo Girão, shown in Figure 4, a very high cliff of 589 meters. ${ }^{17}$ The expedition's main ships moored there, and small boats with men, food and water went to explore the coasts. ${ }^{18}$ The explorer's main goal was to identify landscape details such as watercourses, in some cases collecting samples or tasting different types of freshwater. They then described and named the bays and coves for the first time according to their natural characteristics. In Madeira, during the explorers' trip, many toponyms were given to places according to their natural features, like Porto do Seixo (Pebble Port), after a large rolled rock found there; Camâra de Lobos (sea lions' chamber) due to the presence of a large number of these animals in that area; or even Funchal (fennel) as the large bay was surrounded by a valley full of fennel plants.

Among the three captaincies of Madeira, during the fifteenth century Funchal became the most prominent, due to its geographical location and to the growth of its port city, boosted by the increase of sugar agro-manufacturing. ${ }^{19}$ One of Funchal's most important aspects was the protected western part, with two islands forming a calming cove. Land settling started from this point, with the first houses and churches being erected there. This zone was the best-protected area for ships, despite Funchal's very large bay.

17. Gaspar Frutuoso, Saudades da Terra (Ponta Delgada, 2005), II, 18.

18. Usually these explorations were made during the summer time with good weather and calm sea.

19. Funchal was elevated to town status in 1445 . 
In the Caribbean, among the phenomena noted by the very first observers, such as on Columbus' expeditions to Jamaica, was the presence of indigenous people and their reaction to the European presence. ${ }^{20}$ One aspect of these first contacts was their conditioning of the choice of settlement places in the Caribbean, as well as in the Canary Islands, ${ }^{21}$ but not in the Azores or Madeira. The available sources allow us to identify another important feature of the Europeans' original observation of the islands. Place naming occurred, according to the sources, based on the explorers' first perceptions of the most important natural elements in the landscape. The toponym 'port', for example, was commonly used to designate bays. Also, the shape of the land and how it seemed in terms of agricultural potential could define the place's name: arable land, fertility and watercourses. Hernando Colon, during his exploration of the Jamaican coasts in 1494, commented: 'it is beautiful with great fertility, has excellent ports and the coast full of people'. ${ }^{22}$ Some of the places received a name related to harbour conditions, such as Puerto Bueno (Good Port) in the north of the island.

The Portuguese word 'angra' means 'cove', which was the name given to Terceira's most protected bay. In Table 1, the word 'port' as a name for a place or settlement is listed to understand the incidence of this name in each of the case studies, to verify whether the bays were considered good enough to attribute port functions to them. Another significant issue relating to port placement choices was the fact that even the most protected location might be vulnerable. If insular ports were exposed to bad weather from uncovered directions, shipping had little chance of escape. It is therefore important to evaluate whether or not this vulnerability influenced harbour positioning and functioning. In the case of Angra, this vulnerability was often mentioned because ships could not exit the bay if bad weather turned south suddenly. More than 80 shipwrecks are on the historical records, ${ }^{23}$ and to date at least 13 archaeological sites have been identified inside the bay. ${ }^{24}$

Of the four case studies, Jamaica is the one with the highest incidence of names related to 'port'. ${ }^{26}$ In this case, it is important to consider the large dimensions of this island

20. Pedro Nuño Colón de Portugal, El memorial colombino de don Pedro Colón de Portugal y Castro, duque de Veragua y de La Vega, marqués de Jamaica, a sua alteza real doña Mariana de Austria, reina regente por D. Carlos II de España sobre la isla de Jamaica (Kingston and San Francisco, CA, 1992 [1672]).

21. David Abulafia, The Discovery of Mankind: Atlantic Encounters in the Age of Columbus (New Haven, CT, 2008).

22. Francisco Morales Padrón, Jamaica Española (2nd edition, Sevilla, 1952), LXVII, 34.

23. Paulo Monteiro, 'A Carta Arqueológica Subaquática dos Açores: Metodologia, resultados e sua aplicação na Gestão do Património Subaquático da Região Autónoma dos Açores', Actas do $3^{\circ}$ Congresso de Arqueologia Peninsular (Porto, 2000), 497-519.

24. Direcção Regional da Cultura, 'Carta Arqueológica dos Açores', Centro do Conhecimento dos Açores. Available online http://www.culturacores.azores.gov.pt/paa/ca/Default.aspx [accessed 13 April 2016].

25. In this case Angra has been considered to be in the same category according to its meaning 'creek', 'protected bay' or 'port'.

26. William B. Goodwin, Spanish and English Ruins in Jamaica, with a Brief History of that Tropical Paradise Since it was Discovered by Christopher Columbus, the Great Navigator, and Settled by his Son, Don Diego Colon in 1509 as Duke of Veragua (Boston, MA, 1946), 118-19. 
Table I. Port or harbour toponyms.

\begin{tabular}{|c|c|c|c|}
\hline Terceira & Madeira & Barbados & Jamaica \\
\hline Angra $^{25}$ & $\begin{array}{l}\text { Porto Moniz } \\
\text { (Moniz Port) }\end{array}$ & $\begin{array}{l}\text { No port or harbour toponyms } \\
\text { only the term 'bay' associated } \\
\text { with anthroponyms }\end{array}$ & Port Maria \\
\hline Porto Novo (New Port) & & Carlisle Bay & \\
\hline Port Judeu (Jewish Port) & $\begin{array}{l}\text { Porto Novo } \\
\text { (New Port) }\end{array}$ & Austins Bay & Port Antonio \\
\hline Porto Martins (Martin Port) & Porto da Cruz & Fowle Bay & Port Morant \\
\hline $\begin{array}{l}\text { Porto de S. Fernando (San } \\
\text { Fernando Port) }\end{array}$ & (Cross Port) & Constanis Bay & Hold Harbour \\
\hline \multirow[t]{4}{*}{ Porto Negrito (Bold Port) } & & Clarkes Bay & Port Royal \\
\hline & & Balises Bay & $\begin{array}{l}\text { Puerto Escondido } \\
\text { (Hidden Harbour) }\end{array}$ \\
\hline & & Spykeses Bay & Long Harbour \\
\hline & & & Dry Harbour Pan \\
\hline
\end{tabular}

compared with the others and the large incidence of 'good bays', from a geomorphological perspective. Some of the names where the word 'port' is used are also associated with a second word regarding natural characteristics, such as Porto Negrito in Terceira, or Puerto Escondido and Long Harbour in Jamaica. But the majority of the second names have anthroponymic origins such as: Porto Moniz, Port Maria, Port António or Porto Martins.

In Bridgetown, the bridge built on the small river flowing east to west - Constitution River - gave the town its name. The bay in front of the port was named Carlisle Bay after the island's second Lord Proprietor, James Hay, first Earl of Carlisle, who claimed the island through a Royal Grant in 1627.27

In Jamaica, as in Terceira, settlement began on the northern coast due to navigation issues. ${ }^{28}$ In the case of Jamaica, explorers came from Cuba, north of Jamaica. The Spanish were the first to explore the island. According to their descriptions, ${ }^{29}$ the southern coast was considered better than the northern, since it was closer to the American continent where the important enterprises, such as silver mining, were located.

As for the Azores, the same use was spatially verified in Angra. Throughout the sixteenth century, this port was considered the best in the archipelago and even in the entire mid-North Atlantic, and it became essential for a 'return by the circle route' (volta pelo largo). ${ }^{30}$ The bay, closed and well protected, could provide Portuguese ships coming

27. Vincent T. Harlow, A History of Barbados 1625-1685 (Oxford, 1926), 4.

28. Explorers began the first establishments on the northern coast and then went down to the south cost of the island investigating the geography of the shores.

29. Francisco Morales Padron, Jamaica Española, Prólogo de D. Vicente Rodríguez Casado. Publicaciones de la Escuela de Estudios Hispano-Americanos de Sevilla (Sevilla, 1962), LXII, 33-54.

30. Bailey W. Diffie, Foundations of the Portuguese Empire, 1415-1580 (Minneapolis, MN, 1977), 136; Daniel R. Headrick, El Poder y el Imperio: La Tecnologia y el Imperialismo, de 1400 a la Actualidad (Barcelona, 2011), 31. 
from the Indian Ocean with water, ${ }^{31}$ repair or healthcare facilities. For this purpose, a specialized office was created for the protection and assistance of Portuguese ships crossing the Azores, called Provedoria das Armadas, ${ }^{32}$ which was led by the provedor ('Purveyor of the Armada of the Islands'). The long trips wore out both ships and passengers, and as the Azores were positioned exactly on the route of trade winds and currents, this made them vital for the success of Portuguese imperialism and trade with Africa, the East Indies and Brazil.

In Madeira, according to the navigation system, ships bound for South Africa, India or the Americas would call for replenishment. ${ }^{33}$ But Funchal asserted its commercial role in the sugar and wine trades, which became important commodities in the development of the Portuguese Empire during the seventeenth and eighteenth centuries. In this context, Funchal's physical space satisfied this trade because of its large bay that allowed many ships to be safely loaded with goods. The loading and unloading was conducted in small boats that carried goods from Funchal's large gravel beach.

Barbados, after being discovered, did not attract the Spanish. Although they recognized the island, they never used it: 'fortunately for the islands they came, and saw - and passed on: seeking the greater glories of the main land?' 34 Only ships catching the trade winds, beating up to the north, could reach Barbados. They had registered the Barbadian landscapes, but did not stop for anything. Nothing tempted them to go there, not even the need for water, as that was scarce on the island, anyway. ${ }^{35}$

Only in 1627 did the British decide to explore and settle in Barbados, with Henry Powell commanding the mission. The first landing place in the island was named Jamestown, located on the west side of the island with a good bay where explorers immediately felled trees to build houses close to the shore. ${ }^{36}$ But Bridgetown soon grew because of its natural advantages as a port, with a calm bay, ideal for trading. This natural harbour provided a safe anchorage inside the bay. Therefore, the settlement quickly developed infrastructures such as wharves and shipyards, essential to support the shipment of sugar that rapidly became the island's main product.

31. A. J. R. Russell-Wood, The Portuguese Empire 1415-1808: A World on the Move (London, 1998).

32. José G. R. Leite, 'A estrutura da provedoria das Armadas de Angra no século XVIII: Uma visão burocrática', in Portos Escalas e Ilhéus no Relacionamento entre o Ocidente e o Oriente: Actas do Congresso Internacional Comemorativo do Regresso de Vasco da Gama a Portugal, Ilhas Terceira e S. Miguel (Lisboa, 2001), I, 295-308; Artur Teodoro de Matos, 'As escalas do Atlântico no Século XVI', Biblioteca Geral da Universidade de Coimbra (Coimbra, 1988), 1; Maria Fernanda Dinis Teixeira Enes, 'A Provedoria das Armadas no Século XVII (Algumas Notas): Os Açores e o Atlântico (séculos XIV-XVII)', in Actas Do Colóquio Internacional Realizado em Angra do Heroísmo de 8 a 13 de Agosto de 1983 (Angra do Heroísmo, 1984), 147-76.

33. Albert Silbert, Uma encruzilhada do Atlântico Madeira (1640-1820) (Funchal, 1997), IV, $75-121$.

34. Harlow, A History, 1.

35. McD Beckles, A History, 8 .

36. Charles I granted the settlement of Barbados to James Hay, the first Earl of Carlisle, who assumed responsibilities for the defence and administration of the island. Harlow, A History, 4. 
The presence of Arawak Indians in Jamaica, ${ }^{37}$ when Columbus discovered the island, restricted the free choice of good places to settle, in contrast to the experiences of Madeira, the Azores and Barbados. ${ }^{38}$ Despite having good bays, lands and natural good ports, the Spanish had to face human occupation first, which meant, in most of the cases, conflicts and domination by force towards the local population. In Terceira, Madeira and Barbados, access to and settlement on favourable landscapes was limited only by the characteristics of natural elements such as gullies, cliffs and riversides that might prevent entry to the territory. Despite Columbus' description of Jamaica as 'the fairest island that eyes have beheld', it was full of villages populated by 'unfriendly Indians' ${ }^{39}$

Port Royal emerged during the seventeenth century and quickly became the most important harbour in Jamaica. It proved of great strategic value when the first English fleet arrived in 1655, landing in the bay where Port Royal would grow, and where Kingston Harbour is today. Named by the Spanish 'Cayo de Carena', this site became a starting point for the conquest and control of the most important Spanish settlement, 'Santiago de La Vega', or simply 'Spanish Town' to the English. ${ }^{40}$ To sustain this military position, the English had to fortify this site, naming it 'Cagway'. Quickly, fortifications and houses were built and the small garrison was soon transformed into a town named Port Royal.

Port Royal differs from the other case studies in that it emerged for military reasons and not through its natural suitability as a port. Moreover, historical and archaeological data indicate that Port Royal was not occupied by indigenous people despite its good position, and was only used for fishing. ${ }^{41}$ In fact, Port Royal's shore had all the requisites for a port: deep water close to land, good anchorage, protection from waves and winds, and well positioned for defensive purposes.

37. The name of the island came from an Arawak term, Xaymaca that means 'well wooded and watered'. So the land has a lot of forests and water and this was an important aspect for the indigenous population and the Europeans colonizers. John Ogilby and William Wemyss Anderson, A Description and History of the Island of Jamaica, Comprising an Account of its Soil, Climate, and Productions, Shewing its Value and Importance as an Agricultural Country, and a Desirable Place of Residence for Certain Classes of Settlers (Kingston and New York, 1851), 18.

38. In 1536, the Portuguese explorer Pedro A. Campos found Barbados completely deserted despite it having been occupied by Arawaks according to archaeological data. McD Beckles, A History, 3.

39. Clinton V. Black, The History of Jamaica (London, 1989), 20.

40. Clinton V. Black, Spanish Town: The Old Capital (Spanish Town, 1974), 11.

41. According to archaeological data, pre-Columbian archaeological sites across most of the country are in caves or at midden sites. The highest number of archaeological sites are located on the northern coast and in caves positioned on the south coast. Philip Allsworth Jone and Richard Knisely Marpole, 'Pre-Columbian Jamaica: The Sites in the Landscape', Association International for Caribbean Archaeology (2011), 210-19; Basil Reid, 'Source Arawak Archaeology in Jamaica: New Approaches, New Perspectives', Caribbean Quarterly, 38, No. 2/3 (1992), 15-20; William F. Keegan, 'West Indian Archaeology 1: Overview and Foragers', Journal of Archaeology Research, 2, No. 3 (1994), 255-84. 
The port-city started to develop commercially in line with its trading and mercantile needs. As in Barbados, sugar production, together with tobacco and cacao growing, proceeded apace on the island. To ship this produce it was necessary to improve the infrastructure to cater for the increasing number of ships in the harbour. However, geological and tectonic instability trapped those who invested in the port-city. The strong earthquake on 7 June 1692, followed by an equally destructive tsunami, almost completely destroyed Port Royal. ${ }^{42}$ Half of the city sank in the waters of 'Chocolata' hole, where most of the port structures were located. Wharfs, warehouses, shops, taverns and houses were all destroyed and more than 2000 people died, according to the log of HMS Guernsey, registered on 22 June 1692.43 This incident forced the locals to rebuild the port-city's infrastructure, which was both difficult and expensive. The good and strategic location turned out to be unsafe for people and ships, leading to its abandonment as the island's principal port from 1692 onwards, a role assumed by Kingston, further to the north.

\section{Natural constraints on port improvement}

No artificial port structures had been built in these ports before the arrival of the Europeans. Judging potential to landward was essential to understanding how to optimize a site, while factors such as defence, military operationalization and sea access were important. In the insular context of closed bays, the high cliffs themselves functioned as natural defensive elements and as optimal places for coast control.

In all case studies, most of the fortifications or walls were only built in areas where natural features were insufficient for defensive purposes, such as in areas where there were no cliffs. Higher points were good for defence and control of coastal actions from any possible enemy approach, and that is where most of the bulwarks were built. In Terceira and Barbados there were complex systems of forts and bulwarks on the south coasts, proving that defence was important once the chance of enemy attack was high. In low-lying Port Royal, the topography of the city required a good defence system, consisting of strong walls and four forts - Fort Charles, Fort James, Fort Carlisle and Fort Rupert - each with its own quay. By using these systems and a control tower, it was possible to watch all shipping movements around the port, mainly from the southerly and eastern approaches pursued by most ships.

In Funchal, the cliff was steep enough to render fortifications around the coast superfluous. However, there were seven forts in the city to defend the port, more than in any other case. In Angra and Funchal, the Portuguese imperial systems required the existence of controlled sea-gates. Figure 5 shows how the gates of Angra and Funchal limited land access. In Angra there were a total of four controlled sea-gates and in Funchal there were nine. To cross these gates it was necessary to go through the city's military and customs control. In the British system, we do not see this type of structures and there was no such type of control.

42. United States Geological Survey, 'Historic Earthquakes: Jamaica 1692 June 07 UTC'. Available online http://earthquake.usgs.gov/earthquakes/world/events/1692_06_07.php [accessed 22 March 2014].

43. Michael Pawson and David Buisseret, Port Royal: Jamaica (Kingston, 2000), 166. 


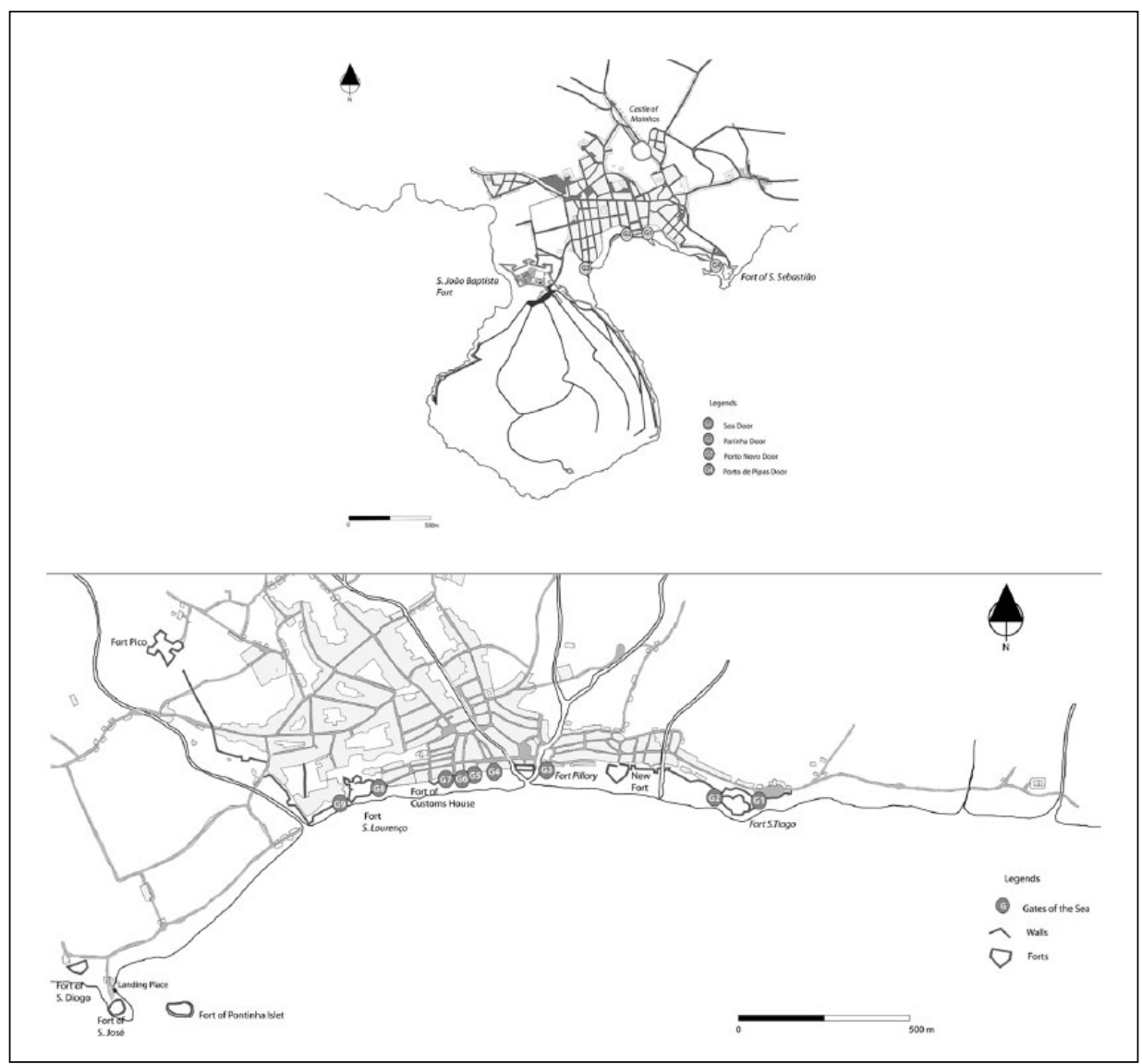

Figure 5. Defensive structures and gate positioning, Angra and Funchal.

Source: Based on (Top) João Baptista Amorim de Freitas. Planta da Cidade D'Angra do Heroísmo, llha Terceira, Escalla Im, por $6250^{m}, 00 . I^{\circ}$ de junho de 1870 .

(Down) Detail of the Plan of the Town of Funchal By Cpt. Skinner, I775. In C.M.F.F, Geo-Hydrographic Survey of the Isle of Madeira with the Dezertas and Porto Santo Islands geometrically taken in the year 1788 by William Johnston Esq. Digested and Published by W. Faden Geographer to the King. London Jan. |st 179I. Plan of the Town of Funchal By Cpt. Skinner 1775.

Within the Portuguese imperial system, customs tried to exert rigorous control. All goods had to pass through the custom gates: 'Porta da Alfândega' in Funchal, ${ }^{44}$ and 'Porta do Mar' in Angra. Funchal had no quays during the seventeenth century, only a small landing structure on the western limit of the port where Forts of S. José and Pontinha were located. Only in the winter was there permission to 'tie the ships in the Islet' ${ }^{45}$ the most protected area of the port. In three documents of the City Hall books it

44. João J. A. de Sousa, O Movimento do porto do Funchal e a Conjuntura da Madeira de 1727 a 1810: Alguns Aspectos (Funchal, 1989), 15-25.

45. de Sousa, O Movimento, 21. 
is logged that 'the capstan was built on the ground just by the sea' ${ }^{46}$ The first was recorded in 1600, the second in 1635, and the third in 1642.

As the Port Royal basin had greater depth, larger ships could come alongside three types of wharf close to shore: military, commercial and common landing places. There were also several private and public wharfs available. Figure 6 shows the design of Port Royal before 1692, where the forts played an essential role in the defence of the city. The private wharfs were owned by trading merchants and managed by local agents in private warehouses, but all other landing types occurred through common landing places, ${ }^{47}$ like the fishery, for example. In the British imperial system, customs control was made directly, in most of the cases, on the landing places and in warehouses by officers who personally inspected the cargo ships to collect taxes. ${ }^{48}$

In Bridgetown, the main function of the harbour was essentially mercantile, with the export of sugar being the main business. On shore, through the Constitution River, ${ }^{49}$ a shipment system was developed in an area known as 'Careenage Place'. Here, the harbour provided a safe anchorage and berthing facilities for small vessels. The larger ships had to anchor far from shore in Carlisle Bay and shipment between land and vessel was undertaken in small boats, ${ }^{50}$ a system similar to that deployed in Funchal and Angra. Also the forts of Bridgetown in opposition are similar to the defensive system at Angra, covering all Carlisle bay as Figure 7 shows.

The major threats to these ports and to the islands were natural catastrophes such as storms, hurricanes, earthquakes and tsunamis, while enemy attacks and piracy were further hazards. For this reason, the provedor das Armadas in Terceira moved to the city of Angra during spring time and stayed there until autumn, when the Portuguese official fleet season ended. ${ }^{51}$ In the Azores, however, local ships and local trade between the islands continued throughout the year, ${ }^{52}$ though it was markedly reduced during the winter. In Funchal, the weather was not as severe as in the Azores, and the trading ships visited the harbour all year long, but less frequently during the winter. ${ }^{53}$

46. Fernando Augusto da Silva, Carlos Azevedo de Meneses and Joel Serrão, 'Cabrestante', Elucidário Madeirense (3 vols., Funchal, 1984), I, 352.

47. Or 'bridge', the word used in the seventeenth century to define a landing stage. Pawson and Buisseret, Port Royal, 132.

48. Pawson and Buisseret, Port Royal, 91.

49. A river that runs from east to west.

50. 'Port Spaces - The Careenage, Wharves, Pier Head, Docks and Carlisle Bay', Barbados World Heritage. Available online http://www.barbadosworldheritage.com/ [accessed 19 December 2014].

51. Garcia, 'O Porto de Angra'.

52. de Sousa, O Movimento, 16.

53. There are no historical official records for Angra concerning seventeenth-century ship movements, only indirect references in local chronicles and city council official records relating to ship licenses such as: António (Padre) Cordeiro, Historia Insulana das Ilhas a Portugal Sugeytas no Oceano Occidental, edição fac-similada da edição princeps de 1717 (Angra do Heroísmo, 1981); Gaspar Frutuoso, Saudades da Terra (Ponta Delgada, 2005); Manuel Luís (Padre) Maldonado, Fénix Angrense (Angra do Heroísmo, 1990); Biblioteca Pública e Arquivo Regional de Angra do Heroísmo, Administração Local, Arquivo da Câmara de Angra do Heroísmo. 


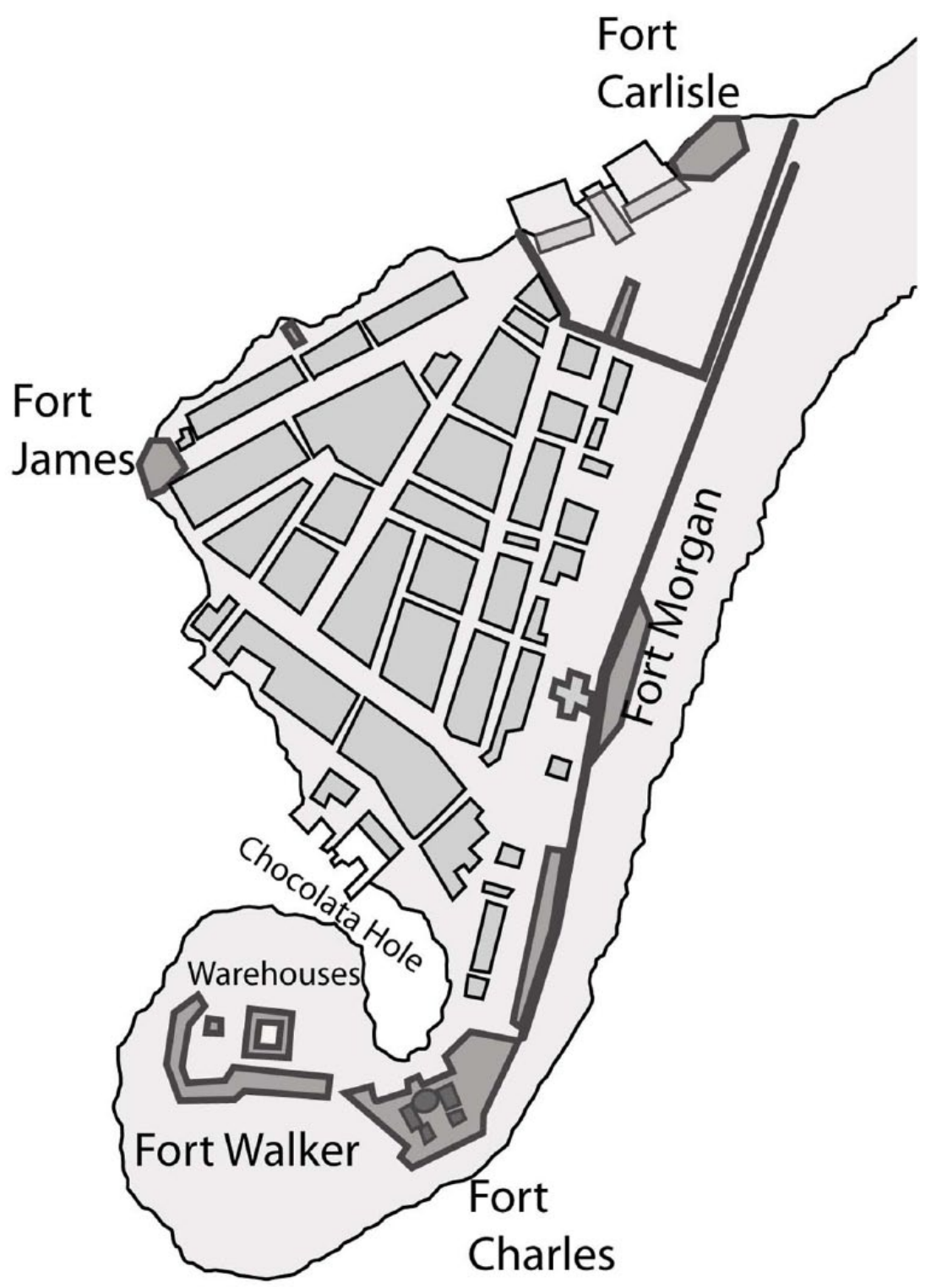

Figure 6. Positioning of main defence structures of Port Royal, I703-1772.

Source: Based on Bellin J.N.; Choffard P-P. 'Plan de La Ville de Port Royal', Le Petit Atlas Maritime Recueil De Cartes et Plans Des Quatre Parties Du Monde en Cinq Volumes. Antilles britanniques - Descriptions et voyages [Illustrations de Description géographique des Isles Antilles possédées par les Anglois] / Choffard, dess. et grav.; (1730-1809). Didot (Paris), I764., Tomo I, No. 58, Series No. 66. Accessed at https://www.loc.gov/ resource/g4964p.ar|95100/ 


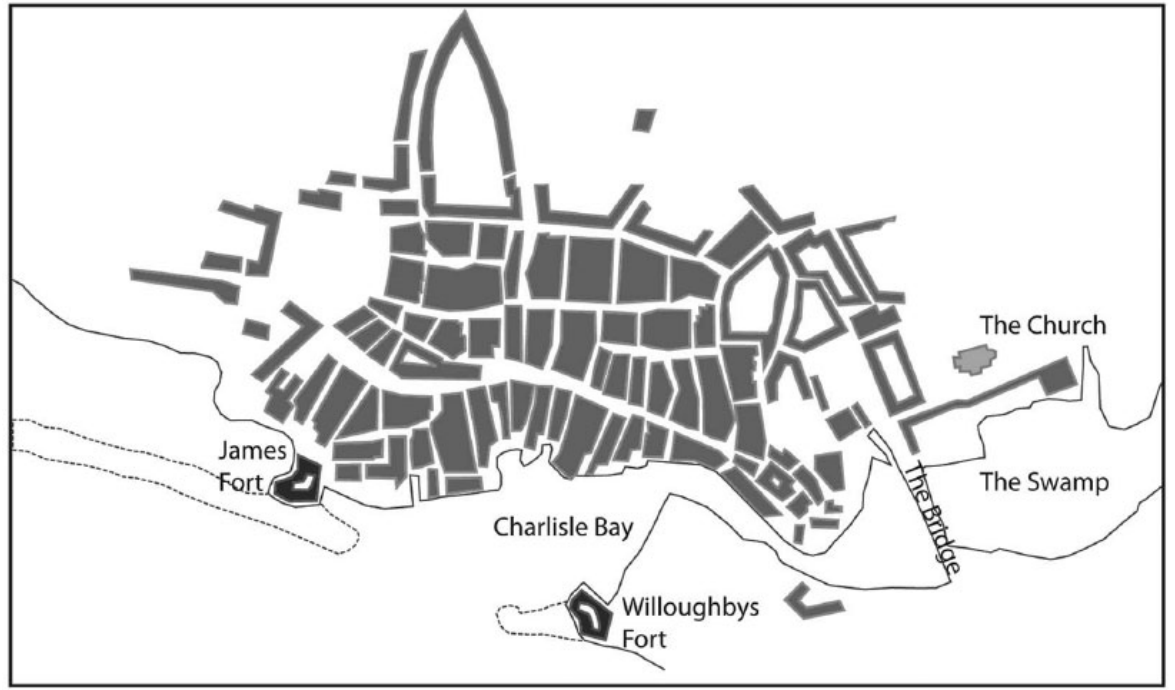

Figure 7. Bridgetown in 1766 based on John Gibson, A Plan of Bridge Town in the Island of Barbadoes (London, I766). First published in the Gentleman's Magazine.

In the Caribbean, the frequency of hurricanes was a serious threat to lives and trade. ${ }^{54}$ Columbus did not encounter this storm season during his first voyage. He had no idea hurricanes existed in his initial report on these islands. After his second voyage, he informed the Spanish king that the Tainos Indians reacted by extending their arms when a storm came saying: 'Furacán, Furacán'. Las Casas also refers to the phenomenon through the testimony of Indians: 'called by the Indians in their language furacan. Now we call them hurricanes'. ${ }^{55}$ The suddenness of these storms was described by Columbus as follows:

The night I arrived there was a great tempest, one that followed me always. And with that tempest, sailing extremely slowly, I reached Jamaica; there the rough sea changed to calm, and great currents took me to the Jardin de la Reina, without seeing any land. From there, when I could, I sailed to Tierra firma, where the wind and a terrible current came from the opposite direction. In all this time I did not enter any harbour, neither could [...] that seemed the end of the world. ${ }^{56}$

This testimony indicates that ports were not safe shelters during storms. The reaction to such occurrences was very similar in Angra. Maldonado describes the case of a

54. The hurricane season in the Caribbean officially runs from 1 June to 30 November, although the peak months for storms tend to be August, September and October. Stuart B. Schwartz, Sea of Storms: A History of Hurricanes in the Greater Caribbean from Columbus to Katrina (Princeton, NJ, 2015), 8-9.

55. Cited in José Carlos Millás, Hurricanes of the Caribbean and Adjacent Regions, 1492-1800 (Miami, FL, 1968), xi.

56. Cited in Martin Fernádez Navarrete, Viajes de Colon, Almirantazgo de Castilla, Con una Carta (Madrid, 1922), 330. 
ship anchored in the port: 'The Nau Caravela to Cape Verde, was taken by surprise because of a strong storm, it tried to escape from inside of the port while in serious trouble' ${ }^{57}$ In this case, it was too late for the ship which sank in Porto Judeu, east of Angra. Such constraints were understood by the masters of the ships. An insular port could become a serious trap when a storm hit; a threat mentioned in most travel guides and atlases. ${ }^{58}$

Another natural catastrophe was tectonic instability, felt more in Angra and Port Royal than in Funchal or Bridgetown. The Azores, due to their active volcanic nature, are always under threat of some tectonic instability. Earthquakes and volcanic eruptions are a frequent phenomenon, as occurred in Vila Franca do Campo on 25 October 1522, when the town, considered at the time the best port-city in San Miguel, was completely destroyed. This example of the Azores has parallels with Port Royal, which, on 7 June 1692, suffered a violent earthquake followed by a tsunami that left half of the place under the sea. Captain Croket described what happened that day, as a 'trepidation or trembling' of the ground:

which in a Minute's time was increased to that degree that several Houses began to tumble down and in a little time after that the Church and Tower, the Ground Opening in several places at once swallowed up multiples of people together, whole streets sinking under water, with Men, Women and Children in them..$^{59}$

About the tsunami that came next he says: 'in this dreadful Concassion several ships in the Harbour, were drove into the Town and lost one whereof was a French Prize, which was drove into the Market place and there lost' ${ }^{60}$

This natural disaster indicated the vulnerability of Port Royal, which led the English to rebuild the most important port-city of the island. The changes on the ground after the earthquake were enormous, which amounted to a re-design of the entire city layout. The natural features of the site proved to the locals, during the catastrophes of the following years, how inappropriate this location was for a port and a city. ${ }^{61}$ However, they tried to rebuild the town in a desperate effort to restore the former glory of Port Royal:

57. Maldonado, Fénix, 2 and 647.

58. See the description of Angra by the French Amédée François Frezier: '[...] the port was bad and small [...] only secure during the summer'. Amédée François Frezier, Relation du Voyage de la Mer du Sud aux Côtes du Chily et du Perou, Fait pendant les années 1712, 1713 \& 1714, Dediée à S. A. R. Monseigneur le Duc d'Orleans, Regent du Royaume. Par M. Frezier, Ingenieur Ordinaire du Roy (Paris, 1716), 283.

59. [Captain Crocket], A True and Perfect Relation of that most Sad and Terrible Earthquake, at Port-Royal in Jamaica (London, 1692); Matthew Mulcahy, 'The Port Royal Earthquake and the World of Wonders in Seventeenth-Century Jamaica', Early American Studies, 6, No. 2 (2008), 404-6.

60. [Crocket], A True and Perfect Relation, 1.

61. The town had been reduced to a 25 -acre island and lost more than half of its inhabitants. Pawson and Buisseret, Port Royal, 169. 
... upon another place, called the Rock, whereon to build a town for the reception and accommodation of merchants [...] capable to receive ships of the greatest burden very night to the shore, which may be much advantage in a small time by the building of wharfs etc. for the benefit of landing and unlading of ships, as at Port Royal before. ${ }^{62}$

After the destruction of 1692, Port Royal suffered in 1703 a tremendous fire that destroyed the city again, followed by a severe hurricane on 28 August 1712 that severely damaged the harbour and, exactly ten years later on the same day, a violent storm which again wrecked half of the city and its harbour. By this time, it had become clear that this location was not fit to be the key British base in Jamaica. As a consequence all structures and services were moved to Kingston, located to the north of Port Royal.

In a different way, but also due to natural disasters, Angra lost its role as the Azores' main port during the eighteenth century, after a series of catastrophes had caused numerous shipwrecks. These were due chiefly to storms, but also human errors committed by shipmasters. The fact is that the royal authorities, after the frequent loss of ships in the port, ordered vessels to avoid calling in Angra because of its dangers. D. Francisco da Gama, Viceroy of India, instructed the captain of the nao Santa Cruz, Diogo de Vaz Freire, to avoid the Azores altogether. Moreover, King Filipe IV ordered the same viceroy: 'on return voyages from India, ships will not stop in Azorean ports' ${ }^{63}$ meaning the traditional call in Terceira. As a result, and since ships still had to replenish somewhere, Angra was gradually replaced by Horta, on Faial Island, and Ponta Delgada, on San Miguel Island, as trade increased between Europe and North America during the second half of the eighteenth century.

In contrast, Funchal and Bridgetown, with their mostly calm and favourable roadsteads, suffered almost no significant disasters, so that they continued to grow as ports and remained important trading posts throughout the early modern era. In this way, they affirmed their place in a context of commercial and political conjuncture for both the Portuguese and British Empires, based mainly on the wine and sugar trade.

\section{Insular ports: Natural characteristics and drivers}

This article is designed to enhance understanding of the Portuguese and English imperial systems by identifying the strategies, choices and functions that underpinned the development of four insular ports in the Atlantic economy. In this respect, environmental conditions were decisive in the choice of settlement locations, ${ }^{64}$ while natural factors shaped the islands' development and that of their ports. In all cases, urban structures were designed by local and central authorities to mitigate the effect of natural elements, but for

62. Pawson and Buisseret, Port Royal, 169.

63. António da Silva Rego, ed., Documentos Remetidos da Índia ou Livros das Monções [...], 'Colecção de Monumentos Inéditos para a História das Conquistas dos Portugueses em África, Ásia e América, Tomo XXI', IX, (Lisboa, 1978), Livro 17, doc. 276, 230-2 (at 232) and Livro 18, doc. 9, 265-6.

64. Headrick, El Poder, 14. 
the most part that was not possible due to technical and financial limitations, as was abundantly evident in the case of Port Royal. During the early modern era, artificial insular port structures - deep water close to shore - could not go beyond the construction of forts, walls or wharfs close to the coastline. All of these were vulnerable to complete destruction if any severe catastrophe occurred.

\section{Author biography}

Ana Catarina Abrantes Garcia has been Research Assistant in the Centre for Global History (CHAM) at the New University of Lisbon and University of Azores since December 2009. Currently a PhD candidate at New University of Lisbon, she gained a Master's Degree in Insular and Atlantic History at University of the Azores in 2009. From May 2001 until December 2011, Catarina worked for the Azores Culture Heritage Department (DRaC), where she focused on Azorean archaeological heritage management. 